\title{
Reuna
}

\section{MOTIVATIONAL FACTORS AND DETERMINANTS OF THE CHOICE OF TIRADENTES AS A TOURIST DESTINATION}

\section{FATORES MOTIVACIONAIS E DETERMINANTES DA ESCOLHA DE TIRADENTES COMO DESTINO TURÍSTICO}

http://dx.doi.org/10.21714/2179-8834/2018v23n2p43-59

\author{
Juliana Maria Magalhães Christino \\ Universidade Federal de Minas Gerais (UFMG), Brasil. \\ E-mail: julianam.prof@gmail.com \\ Thaís Santos Silva \\ Universidade Federal de Minas Gerais (UFMG), Brasil. \\ E-mail: tha.silva25@gmail.com \\ Carla Agostini \\ Instituto de Ensino Superior Presidente Tancredo de Almeida Neves (IPTAN), Brasil. \\ E-mail: carla.agostini@bol.com.br
}

Submissão: 21 Nov. 2017 Publicação: 06 Set. 2018. Sistema de avaliação: Double blind review.

Centro Universitário UNA, Belo Horizonte - MG, Brasil. Editor chefe: Prof. Dr. Gustavo Quiroga Souki

Este artigo encontra-se disponível nos seguintes endereços eletrônicos:

http://revistas.una.br/index.php/reuna/article/view/996

http://dx.doi.org/10.21714/2179-8834/2018v23n2p43-59

\begin{abstract}
Considered one of the 65 destinations inducing the National Tourism, the city of Tiradentes - MG presents average competitiveness similar to other locations. Nevertheless, in order to stabilize and differentiate itself as a tourist destination, the city still needs to improve public policies aimed at tourism, its entrepreneurial capacity to monitor tourist behavior, as well as aspects that promote and characterize a destination image. Aligned with these needs, the objective of this article was to identify the motivational and determining factors that take tourists to Tiradentes. The respondents answered questions related to the factors that motivated their trip to the city and those determining factors for their choice. In general, the tourists were more motivated to visit Tiradentes in the search of relaxation, rest and escape of the day by day. Correlations were found among the motivational factors and the age variable, as well as the length of stay in the city. The influence of the variable marketing and information was highlighted as a determinant of the choice. Based on the understanding that the knowledge of the motivational antecedents of the tourist behavior and its correlates allows to establish more effective strategies of attraction and support, this article outlines an initial path in the search for a differentiating positioning and in the construction of an image and brand of destination of the city of Tiradentes.
\end{abstract}

Keywords: Motivational Factors, Determining Factors, Image of Destiny. 


\section{RESUMO}

Considerada um dos 65 destinos Indutores do Turismo Nacional, a cidade de Tiradentes - MG apresenta média de competitividade similar a outras localidades. Apesar disso, para se estabilizar e diferenciar-se como destino turístico a cidade ainda precisa melhorar as políticas públicas voltadas ao turismo, sua capacidade empresarial, de monitoramento do comportamento do turista, bem como aspectos que a promovam e caracterizem sua imagem de destino. Alinhado a essas necessidades, o objetivo desse artigo foi identificar os fatores motivacionais e determinantes que levam os turistas a Tiradentes. Os entrevistados responderam perguntas relacionadas aos fatores que motivaram sua viagem a cidade e aqueles fatores determinantes para a sua escolha. De maneira geral, os turistas se mostraram mais motivados a visitar Tiradentes na busca de relaxamento, descanso e fuga do dia-a-dia. Correlações foram encontradas entre os fatores motivacionais e a variável idade, assim como o tempo de permanência na cidade. Como fator determinante da escolha destacou-se a influência da variável marketing e informação. Partindo-se da compreensão de que o conhecimento dos antecedentes motivacionais do comportamento do turista e seus correlatos permitem consubstanciar estratégias de atração e suporte mais eficazes, esse artigo delineia um caminho inicial na busca de um posicionamento diferenciador e na construção de uma imagem e marca de destino da cidade de Tiradentes.

Palavras-chave: Fatores Motivacionais, Fatores Determinantes, Imagem do Destino.

\section{Introduction}

Understood as activities, events and memorable and fun perceptions in a destination that involves the travelers personally and positively influence their behavior, their loyalty and customer value, the experiences of tourism, when they become unique and positive, can be a source of differentiation and creation of commitments between destinations and travelers (CETIN; BILGIHAN, 2016). While the tourist markets have become increasingly competitive, the attributes of the destination, different elements that motivate and attract travelers to particular location, are critically important. These characteristics are compared by tourists at the time of choosing a specific destination (KIM, 2014).

The experiences of tourism are undertaken with different objectives and to meet the needs and desires (PREBENSEN et al., 2012). Travelers can try, for example, to contemplate the natural environment, obtain desirable medical treatment, immerse themselves in different cultures, visit the authentic past/remnants of people and places, learn the harmony among the environment, local residents and visitors, or to relieve stress and slow down the pace (OH; ASSAF; BALOGLU, 2014).

As Zhang et al (2014) explain, the attributes and benefits sought at a destination, resulting from the impressions, beliefs and motivations of tourists over time, make up the image of the destination. This image, influences the choice of travelers and is recognized as a significant antecedent of satisfaction of tourism and the behavior after visit (DE NISCO; et al., 2015). The composition of the image of the destination, allied to the tourist loyalty, are central elements in the acquisition of competitiveness to tourist destinations. 
Even though there is extensive literature on tourist motivations, it is essential as Oppewal, Huybers and Crouch (2015) emphasize, to have a set of considerations and knowledge in respect of the motivational factors that lead tourists to a specific destination. The tourist products are typically of high involvement, which generate research activities of information before that consumers undertake themselves with the final choice. For this reason, in order to provide greater competitiveness and more attractive travel experiences, it is necessary to better understand the decision-making process of the tourist and the role of different attributes of the destination and its relationship with the travel motivations (OPPEWAL; HUYBERS; CROUCH, 2015).

Due to the impact they exert on marketing decisions related to segmentation, advertising, product development and positioning of the motivational factors and their correlates, have their importance acknowledged (COHEN; PRAYAG; MOITAL, 2014).

In this context, the objective of this article was to identify the motivational factors and determinants that take the tourists to the city of Tiradentes - Minas Gerais. The city was named by the Ministry of Tourism as one of the 65 Inducing destinations of National Tourism, which assesses the Competitiveness Rate of destinations. According to the latest report available, even though the city has an average of competitiveness similar to non-capital cities, it still needs improvements regarding public policies geared to tourism, services and tourist facilities, entrepreneurship, marketing and promotion of the destination and monitoring of tourists. Still according to the report, the city has as a challenge to create its brand and image as a tourist destination (MINISTRY OF TOURISM, 2015).

Thus, a more detailed knowledge about factors that encourage travelers to know the city, and which contribute to the formation of its destination image, can foster more strategic and accurate initiatives. These can serve so the planning, management decision-making in relation to standards of tourists' behavior and the formation of a competitive destination image (ZHANG et al., 2014).

\section{The city of Tiradentes}

Founded by Bandeirantes Paulistas, the city of Tiradentes arose in mid-1702, in a period known as the Gold Period. With the fall of the exploitation of gold and famous for its objects in silver and wooden craft pieces, the city began to receive investments, arising from partnerships between employers and the public power, for conservation of its historical and cultural heritage. Some decades were enough to consolidate as one of the main tourist destinations in Brazil (BOLSON; FERREIRA; VIEIRA FILHO, 2010).

According to data from the Ministry of Tourism, the town receives tourists from all over Brazil and the world. Its historical attractions, cuisine, handicrafts and ecotourism confer intense programming and attracts visitors throughout the year (NASCIMENTO, 2016). The city counts with the achievement, for example, on film festivals, gastronomy, photography and theater. In addition, due to its historical heritage is considered one of the most preserved in the country, the city is frequent scenario of recordings of movies, miniseries and novels (STATE SECRETARIAT OF TOURISM, 2016).

Tiradentes is part of the 65 inducing destinations of tourism development, elected by the possession of basic infrastructure and qualified tourist attractions, which 
is characterized as a core receiver of tourist flows. The policy of inducing destinations, was started in 2008 by the Ministry of Tourism. This policy provides a study of competitiveness that presents a broad diagnosis on the various aspects that influence the competitiveness in tourist inducing destinations (OBSERVATORY OF TOURISM, 2016).

\section{Theoretical Referential}

\subsection{Image of the destination}

Due to the large number of offerings and options of trips, which in a lot of cases have similar characteristics, it is not enough that a destination be just remembered. On the contrary, it must be considered unique and with different attributes that allow this to be chosen as the final decision (QU; KIM; IM, 2011).

In this scenario, the managers of a destination have resorted to branding strategies to create an identity that focuses on the uniqueness of their products/destinations and to encourage tourists to visit them. The perceived attributes of a brand can influence the strength of the relationship that consumers establish over time. A combination of the destination image and personality of the destination is used as a way to differentiate specific tourist destinations from other competitors (CHEN; PHOU, 2013).

According to Manosso, Bizinelli and Gândara (2013) the image of the destination is a key factor for the creation and development of actions that promote tourist destinations. In addition, it is one of the key elements influencing the choice of tourists. Even that present different constructions as its setting, the image of the destination is commonly associated with the natural and cultural attributes of a destination and its advantages in relation to the others (SMITH; AMORIM; SOARES, 2013).

The image of destinations plays an important role in the construction of the brand and has a direct effect on personality of the destination, and also has a positive effect on the tourist's satisfaction and trust (CHEN; PHOU, 2013). Thus, the strength of this relationship and the consequent power of the image of the destination, will entail advantages when providing the location identification by means of its various tourist products, in a way to stress out the cultural attractions or other attractions, for example, architecture, leisure, demonstrations and traditional and popular uses, parties and celebrations, gastronomy, crafts (FRANCHI CARNIELLO; SANTAELLA, 2012).

As Qu, Kim and Im (2011) explain, the destination image is a multidimensional construction composed by unique cognitive and affective images that impact the tourist behaviors collectively. In addition, it is perceived more positively by tourists who visit a destination more than once, than by those who have their first experience on the site. Thus, since that the consumption of experiences of tourism is relatively infrequent, the positive influence of the image in the recommendations stands out. For potential tourists, the recommendation is an important source of information in the formation of an image toward the particular destination (QU; KIM; IM, 2011).

In this sense, the central element of a destination, in accordance with Nicoletta and Servidio (2012), is its image, which will therefore represent simplified messages of tourist attraction. Its formation is not only composed by processes and marketing strategies, but a combination of subjective and social constructions, based on RELINA, Belo Horizonte - MG, Brasil, v.23, n.2, p.43-59, Abr. - Jun. 2018 - ISSN 2179-8834 
motivational factors. It is noteworthy that the cognitive images, that is, knowledge and information learned about a destination, has significant effects on affective responses of tourists (CHEN; PHOU, 2013).

\subsection{Motivational aspects of tourists}

Being one of the most important constructions of marketing study of tourism, motivation represents a basic driving force of behaviors, and is directly related to the general evaluation (PREBENSEN; et al., 2012). The motivation may be defined as an internal mechanism that leads individuals to act in a certain way so that their specific needs and desires be satisfied (RYAN; GLENDON, 1998).

Due to being intrinsic factor of behavior, each aspirant to tourist will develop several reasons to perform their travel experiences. Thus, it is important to the formation of groups according to similar motivations, homogeneous behavior and preferences of consumption (DE ALCÂNTARA; MATIAS; ARAÚJO, 2012).

As Horner and Swarbrooke (2016) explain, the motivation to perform tourism travel is complex and depends on a number of factors, among them: the personality and style of life of tourists; the past experiences; the person who plans to take a vacation; the demographic characteristics; and; the advance with which reservations for the trip are carried out. Despite this, in a general way, tourists can be classified according to motivations: physical, emotional, personal, personal development, status and culture; (HORNER; SWARBROOKE, 2016).

For the promotion of the image of a destination, careful attention should be taken to correspond to different motivational states that affect tourists (NICOLETTA; SERVIDIO, 2012).

\subsection{Determining factors for choosing tourist destinations}

The choice of tourist destinations, as clarified by Hsu, Tsai and Wu (2009), takes into account a lot of criteria which makes the decision-making process complex. As Massidda and Etzo (2013) point out, a large panel of explanatory variables is taken into account, which comprise from traditional variables driven by economic demand, as factors of price and income, as well as qualitative factors of offerings, such as culture, environment, distance, public security and infrastructure.

Horner and Swarbrooke (2016), classify the determinant factors into two major groups. The first includes internal aspects, such as circumstantial elements (health, income available for spending, time for leisure, own car, etc.); Knowledge (about the destinations, the availability of different products of tourism and price differences among competing agencies); attitude and perception (perceptions of destination and tourism organizations, political views, etc.); and experience (types of holidays, different destinations, previous experiences etc.). The second group comprises the external factors such as: opinions of relatives and friends, activities of the tourism industry marketing, influence of the media, political, economic, social and technological developments at national and global level (HOERNER; SWARBROOKE, 2016).

A combination of the motivational factors and determinants factors can provide the promotion more individual, attractive travel experiences and aligned with the 
demands of tourists (NICHOLAS; MÁS,2006; OPPEWAL; HUYBERS; CROUCH, 2015).

\section{Methodology}

To achieve the desired objectives, a descriptive quantitative approach was performed through the application of a survey to the tourists to the city of TiradentesMG.

The data collection instrument was based on two main constructs: 1) Motivational factors of the tourism experiences in Tiradentes - 15 questions and; 2) determining factors in the choice of experiences of Tourism in Tiradentes - 9 questions (VAZ, 1999; MOTA, 2001; ANDRADE, 2002; MIDDLETON, 2002; LIMEIRA, 2008; COSTA et al., 2010; HORNER; SWARBROOKE, 2016). Questions were also carried out regarding the demographic and specific factors of the trip to the city - 16 questions. The items were measured by means of a Likert scale ( 1 =totally disagree; $5=$ strongly disagree).

The sample was obtained by convenience, collected in the period between March and April of 2013 and was calculated based on the formula for an unknown universe, as proposed by Samara and Barros (1997). The calculation indicated the need to collect at least 384.16 responses and were collected out of a total of 400 responses. It urges to point out that, during the period of data collection, the city was in low season, however the flow of tourists remained significant due to the large number of existing holidays at the time.

Initially, for the data analysis, a descriptive analysis was performed of each construct of the questionnaire through the values of the averages obtained. Subsequently, with the objective of identifying the correlation among the constructs, an Exploratory Factorial Analysis (AFE) was applied. After grouping the factors, the mean for the creation of indicators was used. The correlation among the indicators was performed by means of the Spearman correlation (SIEGAL; CASTELLAN, 2006).

\section{Results}

\subsection{Sample characterization}

The respondents were characterized as to sex, marital status, monthly income, State of residence, time of permanence in Tiradentes and the number of times that had already been in the city. These results are presented in Table 1. 
Table 1 - Sample characterization

\begin{tabular}{|c|c|c|}
\hline & Variables & $\%$ \\
\hline \multirow{2}{*}{ Sex } & Female & $46.8 \%$ \\
\hline & Male & $53.3 \%$ \\
\hline \multirow{4}{*}{ Marital Status } & Married & $51.0 \%$ \\
\hline & Separated/divorced & $5.8 \%$ \\
\hline & Single & $37.5 \%$ \\
\hline & Widow/widower & $5.8 \%$ \\
\hline \multirow{5}{*}{ Family monthly income } & Up to 2,034 & $9.8 \%$ \\
\hline & 2,035 to 3,390 & $15.3 \%$ \\
\hline & 3,390 to 6,780 & $26.8 \%$ \\
\hline & 6,781 to 10,170 & $32.3 \%$ \\
\hline & More than 10,170 & $16.0 \%$ \\
\hline \multirow{4}{*}{ State } & MG & $77.5 \%$ \\
\hline & RJ & $13.3 \%$ \\
\hline & SP & $6.0 \%$ \\
\hline & Others & $3.3 \%$ \\
\hline \multirow{6}{*}{$\begin{array}{l}\text { Time intended to stay } \\
\text { in the city }\end{array}$} & 1 day & $23.0 \%$ \\
\hline & 2 days & $16.3 \%$ \\
\hline & 3 days & $29.0 \%$ \\
\hline & 4 days & $21.0 \%$ \\
\hline & 5 days & $7.5 \%$ \\
\hline & 6 days or more & $3.3 \%$ \\
\hline \multirow{6}{*}{$\begin{array}{l}\text { Number of times been } \\
\text { in the city }\end{array}$} & First time & $29.0 \%$ \\
\hline & Twice & $22.5 \%$ \\
\hline & Three times & $11.5 \%$ \\
\hline & Four times & $9.0 \%$ \\
\hline & Five times & $4.0 \%$ \\
\hline & Six times or more & $24.0 \%$ \\
\hline
\end{tabular}

\section{Source: Research data}

Therefore, in relation to the interviewed tourists, $53.3 \%$ are men and $46.8 \%$ are women. Most of them are married $(51 \%)$, but the city also receives a significant percentage of single ones (37.5\%). These tourists come mainly from the state of Minas Gerais (77.5\%) and Rio de Janeiro (13.3\%).

In addition, most tourists remain in the city from 1 to 5 days (26.8\%), being 3 days a higher reported percentage (29\%). When questioned about the frequency with which they have been in the cities 29 percent of tourists said, with higher percentages, to be the first time, and $24 \%$ reported having visited the city six times or more. 


\subsection{Descriptive analysis of the constructs}

The first construct motivational factors of experience of Tourism in Tiradentes has its means and confidence intervals shown in Table 2.

Table 2 - Means and the confidence interval construct Motivational Factors.

\begin{tabular}{lccc}
\hline \multirow{2}{*}{ Variables } & Means & \multicolumn{2}{c}{ C.I. - 95\% } \\
\cline { 2 - 5 } & & L.I & L.S \\
\hline Escape from the stress of the day to day & 0.53 & 0.49 & 0.56 \\
Relax and rest & 0.53 & 0.49 & 0.56 \\
Practice my favorite sports & -0.28 & -0.33 & -0.24 \\
Learn something new & 0.45 & 0.42 & 0.48 \\
Increase my knowledge & 0.47 & 0.44 & 0.50 \\
Experience other cultures & 0.43 & 0.40 & 0.47 \\
Visit places of interest & 0.47 & 0.44 & 0.50 \\
Visiting friends and relatives & -0.28 & -0.33 & -0.22 \\
Make new friends & 0.36 & 0.32 & 0.40 \\
Satisfy other people & 0.22 & 0.16 & 0.27 \\
Save money & -0.20 & -0.24 & -0.15 \\
Leisure and Entertainment & 0.48 & 0.46 & 0.51 \\
Shopping & 0.05 & 0.00 & 0.10 \\
Attend specific events & 0.08 & 0.03 & 0.13 \\
Know a place of great popularity & 0.19 & 0.14 & 0.24 \\
\hline \hline
\end{tabular}

\section{Source: Research data}

It should be noted that the main variables, which reach higher means and stand out in the perception of the interviewees, and motivate the search experience of tourism in Tiradentes are: "Learn something new", "Increase my knowledge", "Experience other cultures", "Visiting places of my interest", "Make new friends", "Meet other people," "Leisure and Entertainment" and "know a place of great popularity." It is noteworthy that the variables "Escape from the stress of the day-to-day', 'Relax and rest' had the highest averages.

In addition, the variables "Save money", "Visit friends and relatives" and "Practice my favorite sports" present negative mean results, which means that the tourist destination in question is not chosen, under the perception of the interviewees, for these three motivational factors.

In relation to the construct determinant factors in the choice of experiences of Tourism in Tiradentes, the interviewees highlighted the following variables: "Possess compatible price ", "Indications of friends and/or relatives," "Information obtained on the internet", "The distance between the target and the place of residence", "Recommendations for travel agents" and "Being on vacation" as determinants of the choice of Tiradentes. The items of higher average were "Enjoy weekends and/or long holidays" and "Easy Access". These results are presented in Table 3. 
Table 3 - Means and the confidence interval construct Determinant Factors

\begin{tabular}{lccc}
\hline \multirow{2}{*}{ Variables } & \multirow{2}{*}{ Means } & \multicolumn{2}{c}{ C.I. $-95 \%$} \\
\cline { 3 - 5 } & -0.16 & -0.21 & -0.5 \\
\hline Possess compatible price & 0.11 & 0.06 & 0.16 \\
Indications of friends and/or relatives & 0.21 & 0.17 & 0.25 \\
Easy Access & 0.06 & 0.00 & 0.11 \\
Information obtained on the Internet & 0.09 & 0.04 & 0.14 \\
The distance between the target and the place of residence & 0.05 & 0.00 & 0.10 \\
Media publicity & -0.56 & -0.59 & -0.53 \\
Recommendation of travel agents & -0.33 & -0.38 & -0.28 \\
Being on vacations & 0.24 & 0.17 & 0.30 \\
Take advantage of weekends and/or long holidays
\end{tabular}

Source: Research data

It is also possible to note that the respondents neither agree nor disagree with the question "Media Publicity" as a determinant factor of choice for Tiradentes.

\subsection{Correlation between the constructs and their indicators}

After the completion of AFE in each construct, eight indicators were generated. These indicators and their respective component variables are presented in Table 4.

Table 4 - Indicators and variables components

\begin{tabular}{ll}
\hline \multicolumn{1}{c}{ Indicators } & \multicolumn{1}{c}{ Variables components } \\
\hline Construct: Motivational factors & "Relax and rest"; "Escape from the stress of the day-to- \\
Physical and Mental Rest & day" \\
\hline New Horizons & "Visit places of interest"; "Experience other cultures"; \\
\hline Wisdom & "Attend events"; "Make new friends". \\
\hline Leisure cost/ benefit & "Shopping"; "Leisure and Entertainment"; "Save money" \\
\hline Adventure / Family & "Know a place of great popularity"; "Meet others"; \\
& "Practice my favorite sports"; "Visit friends and \\
& relatives". \\
\hline Construct: Determining factors & "The distance between the target and the place of \\
Distance/Off Work & residence", "Easy Access", "Being on vacation" and \\
\hline Price/Information & "Take Advantage of weekends and/or long holidays" \\
\hline Marketing & "Possess compatible price" and "Information obtained \\
\hline
\end{tabular}

Source: Research data 
After forming the indicators, in order to determine associations between the motivational factors and the factors that determine the choice of experiences of tourism in the city of Tiradentes, the correlation of Spearman was held, Table 5.

\section{Table 5 - Correlation among the indicators}

\begin{tabular}{|c|c|c|c|c|c|}
\hline $\begin{array}{l}\text { Correlation among the } \\
\text { indicators }\end{array}$ & $\begin{array}{c}\text { Physical } \\
\text { and } \\
\text { Mental } \\
\text { Rest } \\
\end{array}$ & $\begin{array}{c}\text { New } \\
\text { Horizons }\end{array}$ & Wisdom & $\begin{array}{c}\text { Leisure } \\
\text { cost } / \\
\text { benefit }\end{array}$ & $\begin{array}{l}\text { Adventure } \\
\text { / Family }\end{array}$ \\
\hline Distance/Off Work & $0.157^{\star}$ & $0.288^{*}$ & 0.092 & $-0.188^{*}$ & -0.020 \\
\hline Price/Information & $-0.109^{\star}$ & -0.060 & 0.047 & $0.397^{\star}$ & 0.123 \\
\hline Marketing & $0.154^{*}$ & $0.365^{\star}$ & 0.130 & -0.027 & $0.101^{*}$ \\
\hline
\end{tabular}

* The values in bold were significant $(p$-value $<0.05)$

Source: Research data

Thus, it is noteworthy that the indicator "Physical Rest and Mental Health" is positively correlated with the indicators "Distance/Off Work" and "Marketing". That is, for those respondents who are motivated to visit Tiradentes in search of "Physical and Mental Rest", the variables clustered in the factor "Distance/Off Work" ("the distance between the target and the place of residence", "Easy Access" and "Take Advantage of weekends and/or long holidays"), were determinants of the choice as well as the variables of the factor "Marketing" ("the Media Publicity", "Recommendation of travel agents" and "Indication of friends and/or relatives").

In addition, there is a negative correlation of the indicator "Price/Information" with the indicator "Physical Rest and Mental Health". Thus, for those respondents who are motivated to visit Tiradentes in search of "Physical and Mental Rest", the variables grouped in the factor "Price/Information" ("Possess compatible price" and "Information obtained on the internet") were not determinant of the choice , i.e., for this audience these indicators were not impacting on the final choice for the destination.

Whereas the indicator "New Horizons" is positively correlated with indicators of "Marketing" and "Distance/Off Work". That is, for those respondents who are motivated to visit Tiradentes in search of "New Horizons", the variables grouped in the factor "Marketing" ("Media Publicity", "Recommendation of travel agents" and "Indications of friends and/or relatives") were determinants of the choice, as well as the variables of the factor "Distance/Off work" ("the distance between the target and the place of residence", "Easy Access" and "Take Advantage of weekends and/or long holidays").

The results of the indicator "Wisdom" demonstrate its positive correlation with the indicator "Marketing". Therefore, for those respondents who are motivated to visit Tiradentes in search of "Wisdom", the variables grouped in factor "Marketing" ("Media publicity", "Recommendation of travel agents" and "Indications of friends and/or relatives") were determinants of the choice.

Regarding the construct "Leisure Cost/Benefit ", two correlations are outlined in Table 5. The first, in a positive sense, refers to the construct "Price/Information", which points that for tourists who are motivated in search of "Cost/Benefit Leisure", the variables grouped in factor "Price/Information" were determinant of the choice. 
However, this construct has a negative correlation with the indicator "Distance/Off work in the workplace". That is, for those respondents who were motivated in search of "Cost Benefit/Leisure" the variables grouped in the factor "Distance/Off work" ("the distance between the destination and place of residence", "Easy Access", "Being on vacations " and "Take Advantage of weekends and/or long holidays") are not determinant of the choice, i.e., for this audience these indicators did not stimulate the final choice for the destination.

Whereas in the indicator "Adventure/Family" the positive correlation with the indicator "Marketing" stands out. What represents, for those respondents who are motivated to visit Tiradentes in search of "Adventure/Family", the variables grouped in factor "Marketing" ("Media Publicity", "Recommendation of travel agents" and "Indications of friends and/or relatives") were determinants of the choice. However, this indicator was shown to be negatively correlated to the indicator "Distance/Off work".

For those respondents who were motivated in search of "Adventure/family" the variables grouped in the factor "Distance/Off work" ("the distance between the destination and place of residence", "Easy Access", "Being on vacations " and "Take Advantage of weekends and/or long holidays") are not determinant of the choice, i.e., for this audience these indicators did not stimulate the final choice for the destination.

Finally, it was sought also the correlation among the indicators present in the construct motivational factors with the variable age. These results are presented in Table 6.

\section{Table 6 - Correlation Motivational factors and age}

\begin{tabular}{l|c|c}
\hline \multicolumn{1}{c|}{ Correlation } & Age & Stay Time \\
\hline Physical and Mental Rest & -0.015 & $\mathbf{0 . 1 9 4}^{\boldsymbol{*}}$ \\
New Horizons & -0.028 & $\mathbf{0 . 2 9 2 ^ { * }}$ \\
Wisdom & 0.072 & $\mathbf{0 . 1 4 0}^{\boldsymbol{*}}$ \\
Leisure cost/ benefit & $\mathbf{0 . 1 8 4 ^ { \star }}$ & $\mathbf{0 . 1 8 1 ^ { * }}$ \\
Adventure / Family & $-\mathbf{0 . 1 1 0 ^ { * }}$ & $\mathbf{0 . 2 5 6 ^ { * }}$ \\
\hline
\end{tabular}

${ }^{*}$ The values in bold were significant ( $p$-value $\left.<0.05\right)$

Source: Research data

Note that the indicator "Cost/Benefit Leisure" is positively correlated to the age variable. That is, the greater the age of the interviewee, the more he or she tends to agree with the requirements of this item. In addition, this variable was correlated negatively with the construct "Adventure/Family", indicating that the lower the age of the respondent the more he or she tends to agree with the requirements of this item.

The time of permanence of tourists in the city also proved to be positively correlated with all indicators that compose the motivational factors. Thus, the longer the interviewee remains in the city, the more he or she tends to agree with the requirements of this indicator.

\section{Discussion of results}

As a strategy to increase the attractiveness of a tourist destination, it is important to segment the market of travelers on the basis of socio demographic factors and their motivations (CHO; BONN; BRYMER, 2014). This optic, upon providing an overview of RELUNA, Belo Horizonte - MG, Brasil, v.23, n.2, p.43-59, Abr. - Jun. 2018 - ISSN 2179-8834 
why tourists want to visit regions and cities, back up the development of marketing and tourism policies that maximize the experience of traveling and are significant for the subsets of individual consumers. This article identified the factors that motivate individuals to elect Tiradentes as a tourist destination and the subsequent determinants for its choice.

In this sense, from the analysis of the results, it is perceived that tourists traveling to Tiradentes are motivated mainly for the pursuit of relaxation and rest, and for a desire to escape from the stress of the day-to-day, components of the indicator Physical and Mental rest. These motivations, as clarified by Oh, Assaf and Baloglu (2014), are part of a trend of tourism called slow tourism. The concept is relatively new, often related to sustainable tourism. However, in recent years, had its focus also directed to a practice of time and space, in order to promote the personal satisfaction and well-being. That is, it is a reflex consequent of the resistance to a rising pattern of life style in search of an opportunity to slow the pace, release stress and/or restore and enrich himself or herself (OH; ASSAF; BALOGLU, 2014).

Even though these motivations have the highest averages, it is important to realize that they may vary according to the tourist profile. Since the city of Tiradentes receives visitors with different demographic profiles, for example, tourists, single and married, of different ages and with different periods of stay in the city, it was expected that the correlations between the motivational factors and the age variable be different.

Thus, significant correlations were found between the physical and mental rest indicator with the age variable, which may indicate that this motivational indicator is present in the various age groups of tourists when they are motivated to visit the city of Tiradentes as a tourist destination.

However, the correlation with the age variable showed significant correlation with other motivational indicators. For example, the motivation for shopping in the city, for the search for pleasure and fun and save money are more present in tourists with higher age. Under this aspect, Patuelli and Nijkamp (2016) corroborate pointing out that at world level it has become more popular, in older segments of tourists, the motivation for leisure travel. This profile of traveler, according to the authors, has experienced an increase in life expectancy, better health conditions, more disposable income and greater availability of time (PATUELLI; NIJKAMP, 2016).

Whereas in younger tourists there is greater motivation in choosing Tiradentes, due to the possibility of "knowing a place of great popularity"; "Meet others"; "Practice favorite sports"; "Visit friends and relatives".

Still, it is important to realize the positive correlation present among all of the motivational factors and the time of stay. According to Alén et al. (2014), in an analysis of any tourist destination special attention is required to the time of permanence, mainly due to its close relationship with the tourist income. Tourists who stay longer at destination, visit more attractions and generate more business when compared to those who stay for a short period (ALÉN; et al., 2014). It is identified thus, that the city of Tiradentes receives tourists with motivations that pervades a tendency to stay more than one day, a fact that may generate an input for the development of strategies for support and better service for travelers with this profile.

It is worth noting, in particular, the relationship between the motivational factor New Horizons ("visiting places of interest"; "Experience other cultures"; "Participate in 
events"; "Make new friends") and the time of permanence. These motivational factors comprise what is known as cultural tourism. As stressed by Richards (2009) cultural tourism is considered one of the major areas of growth in global tourism and has become the largest area of development of diversified products by tourist destinations. The authors complement clarifying that the reasons for which the cultural tourists choose a destination is a combination of atmosphere, local culture and history.

In this sense, the correlation found indicate that the motivations toward cultural tourism in the city of Tiradentes are present especially when these remain longer in the city. This result allows that the schedules of events and typical attractions for example, to be based on a schedule that exceeds just one day.

Allied to the motivational factors, it was also examined those that become determinants in the choice of the tourist for the city of Tiradentes. The results allow to infer the importance of marketing factor ("the Media Publicity"; "Recommendation of travel agents"; "Indications of friends and/or relatives"), which showed a significant positive correlation with various motivational factors that led tourists to Tiradentes. Thus, the tourists are influenced by the information they receive from the city, whether through official channels or through the word-of-mouth publicity.

As emphasized by Gulbahar and Yildirim (2015) the tourism sector is guided through information. Therefore, it is important that be aggregated to the marks of destinations new tools of communication technology and social networks. The results found in this study emphasize the need to pay attention to the effects and potential that the media of communication, both official and unofficial, must transmit tourist information about the city of Tiradentes.

In addition, it is important to monitor the kind of experience that is offered to tourists and its consequent satisfaction, which will generate further advertisements and positive and/or negative indications about the city. It is interesting that the tourist destination, through municipal bodies and companies, encourage tourists to tell their experiences of tourism in the city, with details of stories of effective service, through on-line review forums. A visitor satisfaction or dissatisfaction with a destination will influence his or her subsequent behavior (SOTIRIADIS; VAN ZYL, 2013).

According to the authors aforementioned, the increase of social networks and platforms on the internet has become one of the major challenges for the tourist destinations, because they allow tourists to share their experiences with an unrestricted potential. It also changes the way how the tourists seek, read and trust, and also produce collaborative information about suppliers of tourism and tourist destinations (PREBENSEN; et al., 2012; SOTIRIADIS; ZYL, 2013). The general satisfaction of visitors increases to their likelihood to revisit a destination, sharing their experience and recommending (HUI; WAN; CHENG, 2010).

\section{Final considerations}

This study aimed to identify the aspects that motivate and determine the tourists' trips to the city of Tiradentes. It began on the understanding that these factors are an initial path in search of a distinctive positioning and in the construction of an image and brand of destination (USAKLI; BALOGLU, 2011). The knowledge of antecedents of consumer behavior is substantial for the development of effective marketing strategies. 
It was possible to realize, among the main motivations of the interviewed tourists, characteristics of the slow tourism, which provides opportunities for investment in the attributes of the city that provide to travelers, for example, slowing down the pace of life and have access to knowledge of various types. In addition, it is interesting to note that the stay of these tourists in the city exceeds, in its greater part, the permanence of only one day, which favors the existence and consolidation of several tourist attractions. These tourist attractions and events, when planned with greater programming must be related to the cultural elements of the city, since these are factors that were correlated.

Furthermore, it proved to be an extra factor, as a decisive factor in the choice of trip to the city, the access to information, either through friends or travel agents. In this sense, it is important that the city establish channels of official and full information that promote the image of the destination and that can meet the tourists' demands. It is important that attention be also given to feedback of experiences that tourists obtained on the town. Answers and improvements to possible negative returns should be planned, aiming at a positive image of the destination.

As a limitation of the research it is pointed out the nature of the sample, made by convenience and that generated short-term results, i.e., results that portray the perceptions of tourists at a given moment in time, what can delimit generalizations? It is suggested that future studies investigate the motivational factors and determinants of the choice of tourists in the city of Tiradentes during specific events that integrate the annual calendar of the city.

\section{References}

ALÉN, E.; et al. Determinant factors of senior tourists' length of stay. Annals of Tourism Research, v. 49, p. 19-32, 2014.

ANDRADE, J. V. Turismo fundamentos e dimensões. 8 ed., São Paulo: Ática, 2002.

BOLSON, J. G.; FERREIRA, M. A. T.; VIEIRA FILHO, N. A. Q. Os impactos do turismo em Tiradentes: uma análise da percepção do setor público local. REUNA, v. 11, n. 1, 2010.

CETIN, G.; BILGIHAN, A. Components of cultural tourists'experiences in destinations. Current Issues in Tourism, v. 19, n. 2, p. 137-154, 2016.

CHEN, C. F.; PHOU, S. A closer look at destination: Image, personality, relationship and loyalty. Tourism management, v. 36, p. 269-278, 2013.

CHO, M.; BONN, M. A.; BRYMER, R. A. A constraint-based approach to wine tourism market segmentation. Journal of Hospitality \& Tourism Research, v. 41, n. 4, p. 415-444, 2014.

COHEN, S. A.; PRAYAG, G.; MOITAL, M. Consumer behaviour in tourism: Concepts, influences and opportunities. Current Issues in Tourism, v. 17, n. 10, p. 872-909, 2014. 
COSTA, A. C. M.; et al. Análise dos fatores motivacionais e determinantes no processo de decisão de compra do consumidor turístico no entorno do Parque Nacional da Serra da Canastra na região de São Roque de Minas (MG). Revista Brasileira de Ecoturismo, São Paulo, v. 3, n. 2, p. 215-234, 2010.

DE ALCÂNTARA, Felipe Ribeiro; MATIAS, Esdras Matheus; ARAÚJO, Rosalma Diniz. Surfing Trips: Segmentação do Turismo e Aspectos Motivacionais do Surfista. RITURRevista Iberoamericana de Turismo, v. 2, n. 1, p. 93-107, 2012.

DE NISCO, A.; et al. Tourism satisfaction effect on general country image, destination image, and post-visit intentions. Journal of Vacation Marketing, v. 21, n. 4, p. 305317, 2015.

FRANCHI CARNIELLO, M.; AZEVEDO SANTAELLA, L. A imagem turística de São Sebastião (SP). Caderno Virtual de Turismo, v. 12, n. 3, 2012.

GULBAHAR, M. O.; YILDIRIM, F. Marketing efforts related to social media channels and mobile application usage in tourism: Case study in Istanbul. Procedia-Social and Behavioral Sciences, v. 195, p. 453-462, 2015.

HORNER, S.; SWARBROOKE, J. Consumer behaviour in tourism. Routledge, 2016.

$\mathrm{HSU}, \mathrm{T}-\mathrm{K}$; TSAI, Y-F; WU, H-H. The preference analysis for tourist choice of destination: A case study of Taiwan. Tourism management, v. 30, n. 2, p. 288-297, 2009.

HUI, T. K; WAN, D.; CHENG, H. Y. Case study of tourist revisit behavior in Singapore. In: Advances in Hospitality and Leisure. Emerald Group Publishing Limited, 2010. p. $27-4$

$\mathrm{KIM}, \mathrm{J}-\mathrm{H}$. The antecedents of memorable tourism experiences: The development of a scale to measure the destination attributes associated with memorable experiences. Tourism management, v. 44, p. 34-45, 2014.

LIMEIRA, T. M.V. Comportamento do consumidor brasileiro. São Paulo: Saraiva, 2008.

MANOSSO, F. C.; BIZINELLI, C.; GÂNDARA, J. M. G. A imagem da cidade em fotografias online: estudo de caso do site Flickr sobre Curitiba (Paraná, Brasil). Turismo e Sociedade, v. 6, n. 4, 2013.

MASSIDDA, C.; ETZO, I. The determinants of Italian domestic tourism: A panel data analysis. Tourism Management, v. 33, n. 3, p. 603-610, 2012.

MIDDLETON, V. T. C. Marketing de Turismo: teoria e prática. Rio de Janeiro: Elsevier, 2002.

MINISTÉRIO DO TURISMO. Índice de Competitividade do Turismo Nacional Destinos indutores do desenvolvimento turístico regional - Relatório Brasil 2015. Brasília: Ministério do Turismo, 2015. 
MOTA, K. C. N. Marketing Turístico: promovendo uma atividade sazonal. São Paulo: Atlas, 2001.

NASCIMENTO, L. Um passeio por Tiradentes. Disponível em: <http://www.turismo.gov.br/ultimas-noticias/6213-um-passeio-por-tiradentes.html> Acesso: $27 / 10 / 2017$

NICOLAU, J. L.; MAS, F. J. The influence of distance and prices on the choice of tourist destinations: The moderating role of motivations. Tourism Management, v. 27, n. 5, p. 982-996, 2006.

NICOLETTA, R.; SERVIDIO, R. Tourists' opinions and their selection of tourism destination images: An affective and motivational evaluation. Tourism Management Perspectives, v. 4, p. 19-27, 2012.

OBSERVATÓRIO DO TURISMO. Destinos Indutores. Disponível em:< https://www.observatorioturismo.mg.gov.br/ > Acesso: 27/10/2017

$\mathrm{OH}, \mathrm{H}$.; ASSAF, A. G.; BALOGLU, S. Motivations and goals of slow tourism. Journal of Travel Research, v. 55, n. 2, p. 205-219, 2014.

OPPEWAL, H.; HUYBERS, T.; CROUCH, G.I. Tourist destination and experience choice: A choice experimental analysis of decision sequence effects. Tourism Management, v. 48, p. 467-476, 2015.

PATUELLI, R.; NIJKAMP, P. Travel motivations of seniors: a review and a metaanalytical assessment. Tourism Economics, v. 22, n. 4, p. 847-862, 2016.

PREBENSEN, N. K. et al. Motivation and involvement as antecedents of the perceived value of the destination experience. Journal of Travel Research, v. 52, n. 2, p. 253264, 2013.

QU, H.; KIM, L. H.; IM, H. H. A model of destination branding: Integrating the concepts of the branding and destination image. Tourism management, v. 32, n. 3, p. 465-476, 2011.

RICHARDS, G. Turismo cultural: Padres e implicações. In: DE CAMARGO, P.; DA CRUZ, G. (eds) Turismo Cultural: Estratégias, sustentabilidade e tendências. UESC: Bahia, p. 25-48, 2009.

RYAN, C.; GLENDON, I. Application of leisure motivation scale to tourism. Annals of Tourism Research, v. 25, n. 1, p. 169-184, 1998.

SAMARA, B. S.; BARROS, C. J. Pesquisa de marketing. 3 ed., São Paulo: Makron Books, 1997.

SECRETARIA DE ESTADO DE TURISMO. Circuito turístico trilha dos inconfidentes. Disponível em: < http://www.turismo.mg.gov.br/component/content/article/41/415tiradentes > Acesso: 27/10/2017 
SIEGEL, S.; CASTELLAN, N. J. Estatística não Paramétrica para as Ciências do Comportamento. São Paulo: Artmed Bookman; 2006.

SMITH, M.; AMORIM, E.; SOARES, C. O turismo acessível como vantagem competitiva: implicações na imagem do destino turístico. PASOS. Revista de Turismo y Patrimonio Cultural, v. 11, n. 3, 2013.

SOTIRIADIS, M. D.; VAN ZYL, C. Electronic word-of-mouth and online reviews in tourism services: the use of twitter by tourists. Electronic Commerce Research, v. 13, n. 1, p. 103-124, 2013.

USAKLI, A.; BALOGLU, S. Brand personality of tourist destinations: An application of self-congruity theory. Tourism management, v. 32, n. 1, p. 114-127, 2011.

VAZ, G. N. Marketing turístico: receptivo e emissivo: um roteiro estratégico para projetos mercadológicos públicos e privados. São Paulo: Pioneira, 1999.

ZHANG, H.; et al. Destination image and tourist loyalty: A meta-analysis. Tourism Management, v. 40, p. 213-223, 2014. 